\title{
Glimpse of Body Metaphor of Chinese Martial Arts under Embodied Cognition Theory
}

\author{
Xin $\mathrm{SHU}^{1, \mathrm{a},{ }^{*}}$ \\ ${ }^{1}$ Chengdu Sports University, China \\ a1305525071@qq.com
}

Keywords: Martial Arts Body, Cognition, Metaphor.

\begin{abstract}
This paper uses the embodied cognition theory, adopts the method of literature study and logical analysis, and takes the Martial Arts body as the research object through the study of body metaphors of Martial Arts, to promote the awareness of Martial Arts body in practice. This paper puts forward that under the embodied cognition theory, metaphor of Martial Arts body mainly manifests itself in three dimensions, including the body subject which is the logical starting point of body metaphor, awareness space which is the extensive understanding of the body metaphor, and the way of survival which is the reinvention of the Martial Arts body metaphor.
\end{abstract}

\section{Introduction}

The body is a natural entity and a tool to perceive the external objective things. The body's comprehensive response to the external stimuli finally generates a spatial cognition of objective things. "Lakoff and Johnson (1980) pointed out after great amount of analysis and research of metaphor that metaphor means people understand and express the abstract, invisible and complex concepts (such as psychological feelings, social relations, moral, etc.) in the target domain by the means of specific, tangible and simple concepts (such as temperature, space, action, etc.) in the source domain, so as to realize the abstract thinking"[1]. The body metaphor of Martial Arts is a kind of silent language acquired from the continuous interaction between its own body and the external environment and in the process of understanding and cognition. However, the researchers have done little exploration about the embodied cognition of the Martial Arts body. Therefore, the author begins from the cognitive functions of metaphors in the study of embodied cognition, takes body as the starting point, so as to get a glimpse of the cultural and physical values in Martial Arts body metaphor. It will have profound value for better understanding body metaphor and the meaning of Martial Arts.

\section{The Metaphor of Martial Arts Body under Embodied Cognition}

\section{The Logical Starting Point of Body Metaphor: Body Subject}

The body is the source of knowledge of the world, leaving the subject of the body, the cognition of all things will disappear. Only when the body is "present" and intervenes in the brain can the cognition of Martial Arts be accomplished by the practitioner. "The existence of man in the world is not isolated. Human beings interact with the world through body movements and various senses and get to know the world in various ways" [2]. Therefore, the coupling of the body and Martial Arts constitute the 
metaphor of the body subject, and initiate the cultural characteristic of Martial Arts in its practice, that is, to study inside and practice outside.

In the body subject in which Martial Arts intervene, the body will be classified according to "three joints and four shoots", "four strikes" and "terms", transforming the name of every part and link of the body into the Martial Arts terms and vocabulary, which covers the function and meaning of Martial Arts. Martial Arts divide the body into "three joints and four shoots" according to the structure and function, so that each link is assigned symbols and responsibilities of Martial Arts, so as to show forth the genes and elements of Martial Arts culture in which the body is involved. Secondly, the Martial Art divides the body into "four strikes" according to the technology and method. Every gesture and motion of Martial Arts must abide by the "four strikes" rule, showing the different offensive and defensive implications of different parts of the body. Finally, classify in accordance with the "terms"of the body subject. "Hand" can be visualized by Martial Arts as "fist, palm and hook"; "eye" is a metaphor for "eye expression". In a sense, the Martial Arts body metaphor makes movements more figurative and metaphorical. Therefore, Martial Arts contains the physical structure and the feeling of the body-sports experience, but also is integrated with the mind, learning, memory, emotion and other mental processes. "The mind is fundamentally embodied, not only because the whole process of mind must be based on the neural activity, but also because our perceptual and motor systems play a fundamental role in concept formation and rational reasoning".[3] When the practitioner learns new moves and masters new skills, he needs to find out the differences between the movements according to his physical feeling and his experience in sports. With the help of his physical feeling and his experience in sports, the practitioner can examine and monitor their own Martial Arts movements.

Figure 1: Through high definition camera method and measurement method, take front kick as the training content, and select beginner of Martial arts from children, adolescents, the young, the middle-aged and the elderly. Take the starting point and ending of the front kick as the angle standard, provide systematic training for a month for them, and then try to find out numbers completed in $10 \mathrm{~s}$.

Indication: Intensified, doubled and repeated Martial Arts training can make them examine and monitor their own Martial Arts actions so as to improve and enhance the development and strength of the different links of lower limbs of the body subject.

Table. 1

\begin{tabular}{cccccc}
\hline Object of study & children & Teenagers & Youth & The Middle-aged & The Elderly \\
\hline $\begin{array}{c}\text { Before training } \\
\text { (frequency) }\end{array}$ & $4 / 10 \mathrm{~s}$ & $5.5 / 10 \mathrm{~s}$ & $7 / 10 \mathrm{~s}$ & $5 / 10 \mathrm{~s}$ & $4.5 / 10 \mathrm{~s}$ \\
\hline $\begin{array}{c}\text { After training } \\
\text { (frequency) }\end{array}$ & $5 / 10 \mathrm{~s}$ & $7 / 10 \mathrm{~s}$ & $9 / 10 \mathrm{~s}$ & $6.5 / 10 \mathrm{~s}$ & $5 / 10 \mathrm{~s}$ \\
\hline
\end{tabular}

\section{Extensive Knowledge of Body metaphor: Consciousness Space}

"The consciousness of space is first the space of human, especially from the premise of the space between the body and the sense of skin".[4] The space consciousness in Martial Arts is the mastery of the intuitive feeling and the skin visual space in Martial Arts, and then forms a nonrealistic field space on this basis. It is an advanced state and significant mark of Martial Arts body value. In its practice training, it can achieve a space artistic conception where "nobody seems to have" and a form "seems to be real non virtual". 
The consciousness space of Martial Arts body is continuously influenced by "experience" learned in the process of practice, such as the perception of the physical changes and understanding of action connection. In Martial Arts physical training, it is divided into static artistic conception space and dynamic artistic conception space. The dynamic artistic conception space mainly embodies the perfect integration of Martial Arts body and Martial Arts routine. For example, one of Martial Arts movements "a whirlwind foot then splits". i.e. spread his hands and fall with splits, is the instant presentation of action "in reality". While the picture that "a vigorous eagle dives to the ground" which people associate it with is the "the virtual state" of Martial Arts. It can be said that this state of combination rituality with reality is the aesthetic space artistic conception of the Martial Arts body. In the technic attack training in Martial Arts, while practicing Martial Arts routines focuses on "none seems to have", one should always subjectively have the offensive and defensive awareness when practicing Martial Arts, Turning specific routines practicing into combat against an imaginary enemy. The dynamic artistic conception space is mainly stake standing exercise. In the state of relative balance of the body, the chaotic element force in Martial Arts can experience the feeling of the front and back, upper and lower, left and right side of the body, and then continue to carry out a variety of combinations, finally achieve the meticulously perception of the above six sides.

Figure 2: Select a practitioner who has studied Martial Arts for a year and beginner without training, make a practical test through a Taijiquan competition before and after three months of training.

Indication: After practicing physical technic attack activities, students acquire the cognition of consciousness space thinking, so as to enable students to obtain the awareness of technic attack in the training in practice, improve defense consciousness, and achieve the "space artistic conception of technic attack consciousness" in which when Taiji pushing hands practice Taijiquan, though there is no opponent, he can practice as if there were someone fighting with him.

Table 2.

\begin{tabular}{|c|c|c|c|c|c|}
\hline $\begin{array}{l}\text { Research Contents } \\
\text { Obearch } \\
\text { Object }\end{array}$ & $\begin{array}{l}\text { The } \\
\text { opponent } \\
\text { falls to the } \\
\text { ground or } \\
\text { down the } \\
\text { arena (get } \\
3 \text { points) }\end{array}$ & $\begin{array}{l}\text { The opponent } \\
\text { additionally } \\
\text { supports with } \\
\text { one hand or } \\
\text { knee (get } 2 \\
\text { points) }\end{array}$ & $\begin{array}{l}\text { The } \\
\text { opponent } \\
\text { loses the } \\
\text { Weight } \\
\text { and shifts } \\
\text { (get } 1 \text { point) }\end{array}$ & $\begin{array}{l}\text { Total } \\
\text { Points }\end{array}$ & $\begin{array}{c}\text { The analysis results } \\
\text { of attack } \\
\text { consciousness }\end{array}$ \\
\hline $\begin{array}{l}\text { Beginners before } \\
\text { training }\end{array}$ & 0 & 0 & 1 & 1 & $\begin{array}{c}\text { Attack } \\
\text { consciousness is } \\
\text { weak or with no } \\
\text { attack } \\
\text { consciousness }\end{array}$ \\
\hline $\begin{array}{l}\text { Beginners after } \\
\text { training }\end{array}$ & 3 & 4 & 3 & 10 & $\begin{array}{c}\text { Attack } \\
\text { consciousness is } \\
\text { improved } \\
\text { obviously, and is } \\
\text { stronger }\end{array}$ \\
\hline
\end{tabular}

\section{Re-creation of Martial Arts Body Metaphor: Survival Way}

"DeC. Hamilton and Grafton think that action control includes a hierarchical system; the action is characterized by different levels of abstraction" [5]. As a kind of body 
movement, the Martial Art constantly evolves its cognitive ability, which makes Martial Arts body no longer in the original cognitive level, and moves towards the higher cognitive ability and grade system. In a sense, on one hand the Martial Arts develops towards Taoism through the body's skills and technique, on the other hand, it focus more on the governing function of Taoism.

Physical activity is associated with Taoism, which fully demonstrates its ability to manage the body inside and meet an emergency outside, and is pregnant with the abundant survival way. On one hand, in accordance with the principle to manage the body based on the balance of yin and Yang, practice by combining the yin and yang of the body's shape movements and the body's internal organs. The traditional Martial Arts advocate the combination of yin and yang between relaxation and quietness. Relaxation refers to the spiritual and physical relaxation; quietness refers to the quietness of thoughts and emotions, which shows a physical condition of the body comfortable carefree and content. On the other hand, the cognition of Chinese Martial Arts physical activity has practical guiding significance for people's existence and life. It has been far beyond a simple and pure body movement. It can give people a good personality and philosophy to a certain extent to express of Martial Arts way of thinking category. In the process of practicing hold fist solute, experience the specific meaning representation of the Martial Arts etiquette, which specifies the behaviors of every practitioner. Specific to the relationship between Martial Arts and Taoism, it is the idea "to carry forward Taoism through Martial Arts", which is the spirit of daring to bear. Mo-tse advocates non-attack, which presents a concept paradigm that don't "use one's strength to bully the weak;" and the national integrity that the "Martial Arts hero" Huo Yuanjia showed. In short, far-reaching survival rules are in absorbed and metaphoric in the Martial Arts body, which has a practical guidance value for human beings.

Table 3. Analyze based on the differences among hold fist salute, bow ceremony, and worship on bended knees in Martial Arts

\begin{tabular}{cccc}
\hline $\begin{array}{c}\text { Research contents } \\
\text { Research Methods }\end{array}$ & Study of Hold Fist Salute & a bow & $\begin{array}{c}\text { Worship on bended } \\
\text { knees }\end{array}$ \\
\hline Occasion to Salute & $\begin{array}{c}\text { School, classroom, } \\
\text { games, greeting among } \\
\text { peers, etc. }\end{array}$ & $\begin{array}{c}\text { Between teachers } \\
\text { and students more } \\
\text { intimate }\end{array}$ & $\begin{array}{c}\text { Ceremony of a master } \\
\text { accepting an apprentice }\end{array}$ \\
\hline Times to Salute & many times & many times & less \\
\hline Emotional Degree & $\begin{array}{c}\text { Less emotional color, } \\
\text { simply to comply with } \\
\text { the general etiquette } \\
\text { issues }\end{array}$ & $\begin{array}{c}\text { To show respect } \\
\text { and affection. }\end{array}$ & $\begin{array}{c}\text { The worship and respect } \\
\text { of master, and the } \\
\text { discipline of his own } \\
\text { body }\end{array}$ \\
\hline
\end{tabular}

Indication: In the body activities during the process of hold fist salute - bow ceremony - and worship on bended knees, the expression of emotion is gradually changing, ultimately to achieve their own physical discipline.

\section{Conclusion}

The Martial Art is the cultural activity of physical practice, which is not only the link of spreading cultural activities, but also the origin where Martial Arts cognition initiates. The essence of technical attack in the Martial Art and the grasp of offense and defense, the feeling of man himself, the nature and the harmony between man and nature, are the experience progress of the physical activity in Martial Arts. By 
embedding the human brain, the resources of Martial Arts culture can be encoded and integrated, so as to obtain perception. Therefore, in the Chinese Martial Arts training, the first origin is the physical field of the body subject. Only when the subject of the body has the vitality and vigor can Martial Arts cognition be "opened". But no matter whether it is the body subject or sense of space of the body and even the law of survival of Martial Arts body, embodied cognition plays an indispensable role in the formation and development of human cognition, making embodied cognition run through the whole process Martial Arts body cognition and metaphor.

\section{Reference}

[1] Lakoff, G.\& Johnson.(1980).Metaphors We Live by. Chicago. University of Chicago Press.

[2] Yu Junying. Research on Body Metaphor from the Perspective of Embodied Cognition. [J] Journal of Changchun Normal University, 2012, 11:80-82.

[3] Anderson, M. (2003). Embodied Cognition: A Field Guide [J].Artificial Intelligence, (149:91-130)

[4] Zhao Zhi'ang. Space Expansion and Artistic Conception Between the Body and Skin Sense [J]. Henan Social Sciences, 2010, 03:148-152+219.

[5] DeC. Hamilton, A. F., \& Grafton, S. T. (2007). The Motor Hierarchy: From kinematics to goals and intentions. In Y. Rossetti, P. Haggard, \&M. Kawato (Eds.), Sensorimotor Foundations of Higher Cognition, Attention and Performance XXII. Oxford, New York: Oxford University Press. 